\title{
Bargaining in the Shadow of Social Institutions: Competing Discourses and Social Change in Workplace Mobilization of Civil Rights
}

\section{Catherine R. Albiston}

\begin{abstract}
The Family and Medical Leave Act requires employers to provide job-protected leave, but little is known about how these leave rights operate in practice or how they interact with other normative systems to construct the meaning of leave. Drawing on interviews with workers who negotiated contested leaves, this study examines how social institutions influence workplace mobilization of these rights. I find that leave rights remain embedded within institutionalized conceptions of work, gender, and disability that shape workers' perceptions, preferences, and choices about mobilizing their rights. I also find, however, that workers can draw on law as a culture discourse to challenge these assumptions, to build coalitions, and to renegotiate the meaning of leave.
\end{abstract}

ntil recently, the United States was virtually the only major industrialized country without a family leave policy. Employers could legally fire workers who needed time off to care for seriously ill children, ill or injured spouses, or aging and dying parents. Employers could also legally fire workers unable to work due to temporary serious illnesses or injuries. And employers could legally fire women who needed time off for pregnancy, childbirth, or related medical conditions so long as they also denied time off to nonpregnant employees who were unable to work. Time off after the birth of a child remained a benefit provided at employers' discretion, a benefit primarily available to well-paid professional or management workers (Kamerman, Kahn, \& Kingston 1983).

I wish to acknowledge the generous support provided for this research by the National Science Foundation, No. SES-0001905, and by the Sloan Foundation through the Center for Working Families at the University of California, Berkeley. The views expressed here are those of the author and not necessarily those of the National Science Foundation, the Center for Working Families, or the Sloan Foundation. I also wish to thank Jane Collins, Marianne Constable, Lauren Edelman, Howard Erlanger, Myra Marx Ferree, Rosann Greenspan, Arlie Hochschild, Bert Kritzer, Kristin Luker, Stewart Macaulay, Hamsa Murthy, Robert Nelson, Laura Beth Nielsen, Barrie Thorne, and the anonymous reviewers at Law \& Society Review for their helpful and insightful comments on various versions of this manuscript. Please address correspondence to Catherine Albiston, Jurisprudence and Social Policy Program, Boalt Hall School of Law, 2240 Piedmont Avenue \#2150, Berkeley, CA 94720-2150; e-mail: calbiston@law.berkeley.edu. 
Since 1993, however, the Family and Medical Leave Act (FMLA) has provided some workers with a legal right to unpaid, job-protected leave. The FMLA requires covered employers to provide twelve weeks of leave per year to certain workers who need time off for family or medical crises. ${ }^{1}$ Workers may use FMLA leave for childbirth or other temporary disabilities, and both men and women may take leave to care for a sick child, parent, or spouse, or a new child in their family. ${ }^{2}$ The statute protects workers who use leave from retaliatory harassment, termination, and discrimination. ${ }^{3}$ The law also requires employers to provide leave even if they do not allow time off for any other reason. In other words, the statute creates an entitlement because it does not allow employers discretion to deny leave to qualified workers. ${ }^{4}$

New legal rights seem to be an obvious solution to workplace conflict over family and medical leave because they not only create an instrumental tool for enforcement, but also reframe the meaning of leave as a legitimate and important entitlement. Like most civil rights laws, however, the FMLA is primarily enforced through an individual, private right of action that workers must actively claim or "mobilize." Although these formal rights are an important first step, rights mobilization remains embedded within existing practices, deeply held beliefs, and taken-for-granted expectations about work, gender, and disability. This study examines how legal norms and these other institutionalized systems of meaning influence the process of mobilizing FMLA rights in the workplace.

This study builds on a long sociolegal tradition that examines how law interacts with other systems of meaning in particular social settings. For example, empirical research has demonstrated how law can be displaced or transformed by alternative normative systems (Ellickson 1991; Macaulay 1963) or by organizational practices and goals (Edelman, Erlanger, \& Lande 1993; Heimer 1999). Often, however, these studies treat law and other norms as an either/or proposition: either social relationships are ordered according to law, or there is "order without law." Less is known about the complex process through which law interacts with alternative normative systems (Jacob 1992). Although other systems of meaning matter, actors may still draw upon law as a cultural resource to interpret their social experiences and to influence the behavior of

129 U.S.C. \& 2612. Workers who have worked for their employers for less than one year are not eligible for FMLA leave. In addition, workers who work for companies with less than 50 employees are not covered by the FMLA. 29 U.S.C. $\$ 2611$.

229 U.S.C. $\$ 2612$.

329 U.S.C. $\$ 2614,2615$.

4 The statute does, however, allow employers to require medical certification of the need for leave and to deny leave if the worker fails to provide this certification. 29 U.S.C. $\$$ 2613 (see Shiu \& Albiston 1995). 
others. In this way, law and other social institutions act in concert to give meaning to social life.

Law may be most likely to interact with other normative systems when new rights attempt to change long-standing social practices. Civil rights laws in particular often challenge social arrangements that evoke strong normative commitments (Engel \& Munger 1996; Krieger 2000). Actors who mobilize these rights engage not only with legal systems of meaning, but also with the established practices and expectations that rights were intended to change. Consequently, civil rights claims can become a site for contesting, and perhaps changing, the existing cultural frameworks and practices that help construct social life.

The FMLA provides a fertile location to study how law and other social institutions interact because these rights challenge deeply held beliefs about what work and being a good worker mean. For example, the law erodes certain taken-for-granted expectations about work, such as unbroken attendance as the measure of a good worker and employer control over work schedules. It also undermines traditional ideologies about the gendered division of labor in the family by requiring work to accommodate family needs on a gender-neutral basis. And by protecting the jobs of workers who are temporarily too ill to work, it challenges constructions of "disability" and "work" as mutually exclusive categories. By attempting to change these long-standing work practices and implicit assumptions about identity, the FMLA reconceptualizes the relationships among work, gender, and disability, and creates an opportunity for social change.

Although the FMLA attempts to change work, the cultural frameworks that give meaning to work do not disappear overnight. Workers mobilize their rights to leave in workplaces where these cultural frames or schema are likely to persist. Although the law constructs leave-taking as legitimate, implicit norms about work, gender, and disability may construct very different interpretations of the same behavior. The analysis that follows examines how these competing systems of meaning shape workplace rights mobilization and shows how negotiations over FMLA rights can both reinforce and transform deeply entrenched understandings of work, gender, and disability.

The following sections draw on social constructivist theories from both sociology and sociolegal studies to examine how institutionalized conceptions of work influence the process of mobilizing FMLA rights. Using interviews with workers who negotiated leaves in the workplace, I analyze how social context and social institutions affect workers' preferences and choices about mobilizing their rights. I find that both employers' resistance to leave and workers' interpretations of conflict over leave are shaped by 
institutionalized conceptions of work and the good worker, conceptions that incorporate implicit expectations about gender and disability. I also find, however, that workers can draw on law as a cultural resource to challenge these hegemonic conceptions of work and to renegotiate the meaning of leave.

\section{Rights Mobilization, Institutions, and Social Change}

Most studies of rights mobilization and social change focus on landmark litigation or collective action, rather than the micro-level process of informal workplace negotiations (Burstein 1991; Burstein \& Monaghan 1986; Marshall 1998; McCann 1994, 1998; Rosenberg 1991; Schultz 1990). Nevertheless, the earlier, more informal stages of mobilization also matter, because most grievants either negotiate their claims informally or simply "lump it" (Bumiller 1988; Galanter 1974; Miller \& Sarat 1981; Tucker 1993). Accordingly, a complete understanding of mobilization requires attention to the process of mobilizing law in informal as well as formal contexts.

Sociolegal researchers have begun to explore these informal processes in more detail, and they have generally taken a qualitative, interpretive approach to studying informal mobilization (Bumiller 1988; Engel \& Munger 1996; Morgan 1999; Quinn 2000). Like interpretive studies of litigation as a mobilization strategy (see McCann 1994), these micro-level studies examine how rights work as cultural discourses or "schemas," but focus on informal settings and everyday life (Bumiller 1988; Ewick \& Silbey 1998; Hull 2003; Nielsen 2000; Quinn 2000). This cultural approach grows out of broader sociological theories about how cultural schemas constrain consciousness and shape action to conform to, and therefore reproduce, existing social structures (Berger \& Luckman 1967; Bourdieu 1977; Sewell 1992). From this perspective, law is part of the cultural " "tool kit' of symbols, stories, rituals and world views" that people use to make sense of the social world and to solve different kinds of problems (Swidler 1986:273). Of course, law is not determinative; it is only one of many available frames that actors use to construct meaning in social interactions. Nevertheless, actors can mobilize legal rights simply by invoking legal norms to interpret events and to influence behavior in informal interactions (Lempert 1976, 1998; Marshall 2003; Scheingold 1974; Swidler 1986).

Viewing rights as cultural or symbolic resources suggests one potential mechanism of social change: Mobilizing rights, even in informal contexts, can undermine taken-for-granted understandings of social organization and delegitimize conduct previously 
accepted as natural and normal (Engel \& Munger 1996; Sarat \& Kearns 1993; P. Williams 1991). In other words, social transformation is possible through the innovative use of cultural schemas to reinterpret, enact in new ways, and therefore transform social structures (Sewell 1992; Swidler 1986). Of course, law is not exclusively a positive force for change; law may also constrain change by narrowly defining the claims that are possible and by obscuring other avenues for action (McCann 1994, 1998). In addition, legal rights compete with alternative ideologies that shape how actors understand their experiences (Swidler 1986). Although some workplace actors may legitimate taking leave by referencing rights, others may draw on alternative cultural schemas to undermine legal reforms. Accordingly, like formal legal contests, informal rights negotiations can be seen as an interpretive site for both reinforcing and potentially changing social structure.

\section{Alternative Normative Systems and New Institutionalism}

Early path-breaking studies about law and alternative normative systems tended to demonstrate that local norms sometimes displace law in informal settings (Ellickson 1991; Macaulay 1963). These studies had less to say, however, about how legal norms and other norms interact and construct each other, or how alternative normative systems might be connected to, and reproduce, larger social structures. More recently, some scholars have begun to connect alternative normative systems that conflict with legal reforms to broader social institutions (Edelman, Erlanger, \& Lande 1993; Heimer 1999; Nelson \& Bridges 1999). These "new institutionalists" are skeptical of claims of rational action based on preexisting, atomized preferences. Instead, they examine how choices and preferences are shaped by the cultural meanings and material practices that make up institutions. Thus, in the context of mobilization, a new institutionalist approach focuses on how institutions shape actors' expectations and preferences about mobilizing their rights and, in some instances, transform the meaning of legal rights in informal settings.

Sociolegal scholars who employ this new institutionalist approach conceptualize institutions as much more than a particular hospital, university, or firm. Instead, they view institutions as interorganizational cognitive and normative frameworks that both structure and give meaning to human interaction (Scott 1995). In other words, institutions consist of "a web of interrelated norms, social meanings, implicit expectancies, and other 'taken-for-granted' aspects of reality, which operate as largely invisible background rules in social interactions" (Krieger 2000:478). New institutionalists 
posit that institutions are the product of a social process over time through which patterns of social behavior come to be taken for granted and expected. Once these patterns become institutionalized, actors experience them as part of reality, just the way things are, rather than as the collective production of meaning. Nevertheless, although institutions appear to be an objective and impersonal reality, they do not exist apart from the patterned social interactions that reinforce and re-create them (Berger \& Luckman 1967). Over time, however, institutions become self-sustaining because these cognitive structures and taken-for-granted expectations tend to constrain what constitutes legitimate action and to channel behavior in ways that reproduce institutionalized practices,

A new institutionalist approach is well-suited to studying the FMLA because this law challenges deeply entrenched work practices and norms. Indeed, long-standing work norms and expectations seem likely to affect how workers think about using their rights to leave. How do these institutionalized practices and expectations enter the process of rights mobilization? "Agents of transformation"-opponents, friends, co-workers, and family members-influence which cultural frames dominate as they draw on cultural discourses, both legal and nonlegal, to interpret workplace experiences (Felstiner, Abel, \& Sarat 1981). Agents of transformation who deploy these schemas shape how rights holders evaluate their options for mobilization (Felstiner, Abel, \& Sarat 1981; Morgan 1999). Felstiner, Abel, and Sarat (1981) call this interactive process "reactivity," or the way in which actors redefine their perceptions of experience and the nature of their grievance in response to the communications, behavior, and expectations of a range of people, including opponents, agents, authority figures, companions, and intimates (Felstiner, Abel, \& Sarat 1981:638).

Of course, agents of transformation shape rights holders' perceptions by referencing a range of available interpretive frameworks including not only law, but also other cognitive and normative structures that may undermine law. For this reason, informal rights negotiations can be understood as taking place not only "in the shadow of the law" (Mnookin \& Kornhauser 1979), but also in the shadow of other social institutions.

\section{Power and the Social Institution of Work}

In this study, the shadow of social institutions includes two aspects of work that are particularly salient when workers negotiate contested leaves. The first is how power in the employment relation shapes how workers evaluate their options for mobilizing their rights. Employers generally have more power than their employees over the workplace; for example, the at-will employment 
doctrine gives employers broad powers to fire at will, and employers rather than workers typically control work schedules. These modern workplace arrangements reflect an uneasy truce in a historical struggle over control of the schedule and process of work, a truce that the FMLA potentially disrupts (Edwards 1979; Gordon, Edwards, \& Reich 1982; Jacoby 1985; McEvoy 1998; Montgomery 1976, 1987; Thompson 1967; Tomlins 1993).

Unequal power in the workplace can affect rights mobilization in several ways. First, to the extent that power consists of superior strength or resources, employers who have more resources than their workers may be more likely to prevail in conflicts over rights. Second, power includes employers' ability to prevent grievances from becoming full-blown, public conflicts. For example, employers can create internal procedures to divert grievances from public forums (Edelman, Uggen, \& Erlanger 1999). Also, workers may not mobilize their rights if they fear demotion or termination in response (Bumiller 1988; Tucker 1993). Third, power can be deployed to keep grievances from being recognized at all. For example, employers may withhold information or use persuasion to make workplace practices seem natural and normal, rather than problematic or unfair (Felstiner, Abel, \& Sarat 1981; Gramsci 1971; Lukes 1974). Power also operates through more impersonal cultural forces that shape how actors interpret their experiences. For example, institutionalized meaning systems regarding work are often shared not only by the powerful but also by workers themselves. Consequently, these ideologies can shape how actors understand workplace experiences in ways that legitimate and maintain domination (Bourdieu 1977; Foucault 1979; Gramsci 1971; Sewell 1992).

\section{Work, Time, and the Construction of Inequality}

A second salient aspect of the institution of work - the historical connections among gender, disability, and work - is closely related to this third conception of power. Over time, the interconnected and mutually reinforcing systems of meaning among gender, disability, and work have come to form an invisible cognitive framework that gives meaning to leave for family or medical purposes. In particular, seemingly neutral features of work, such as attendance and time invested in work rather than productivity, have come to define "good workers" (Schor 1992; Thompson 1967).

"Work" is a social institution with relatively standard characteristics that seem natural and normal, many of which focus on time. For example, asked to imagine a typical image or standard of "work," our mental image is likely to include certain features: permanent, uninterrupted year-round work and a standard 
forty-hour work week on a five-day schedule, and a schedule typically set and controlled by the employer. Of course, many jobs deviate from this standard, but we mark those deviations by referencing (and thus reinforcing) the institutional norm by speaking of "part-time" work, "night shifts," or "working for oneself." Moreover, work that deviates from the institutionalized standard is often devalued. For example, recent research documents how workers who fail to meet a normative standard of forty-hour work week, a regular schedule, and uninterrupted year-round work sacrifice job security, pay, and benefits (Fried 1998; Hochschild 1997; Kalleberg 1995; Schor 1992; J. Williams 2000). ${ }^{5}$

What do institutionalized work standards have to do with gender and disability? Like many social institutions, work reflects and sometimes reinforces existing relations of inequality. For example, feminist and disability scholars have long recognized that standard work schedules are implicitly gendered and able-bodied because they fail to accommodate family responsibilities or disabilities that require temporary absences from work (Drimmer 1993; Hochschild 1997; MacKinnon 1989; Okin 1989; Oliver 1990; Pateman 1988; J. Williams 1989, 2000). Nevertheless, normative work schedules have become so taken for granted that the barriers they create appear to arise from the personal circumstances of women or people with disabilities rather than from the structure of work itself (MacKinnon 1989; Oliver 1990). For example, caring for family is viewed as a "private" problem, and accommodations for disabilities are labeled as "special treatment." In this way, the role that work's time standards play in re-creating inequality becomes invisible, and penalities for time off become naturalized, just part of the way things are.

Although these aspects of work seem natural and unchanging, work as a social institution is the product and embodiment of history. For example, modern conceptions of work reflect historical struggles to associate work with masculinity and citizenship (Fraser \& Gordon 1994; Kessler-Harris 1982, 2001). Work's structure reflects early-twentieth-century assumptions that the normative worker is a male breadwinner with a stay-at-home wife, and that women only work for "pin money" until they marry and have children (Folbre 1991; Frank \& Lipner 1988; Fraser \& Gordon

5 This institutionalized standard is created and re-created when individuals act as if it were an objective reality, something naturalized and apart from the behavior that enacts it. As Berger and Luckman (1967) note, however, institutions are socially constructed; they do not exist apart from the beliefs and practices that help construct them. The socially constructed nature of institutions leaves them open to change as these beliefs and practices change over time. As I discuss later in this article, legal rights can facilitate change because rights provide a new interpretive framework for understanding the human interactions that make up work. 
1994; Glenn 2002; Okin 1989; Pateman 1988). Modern work practices also reflect how individuals with disabilities were historically segregated and excluded from civic life (Finkelstein 1980; Harlan \& Robert 1998; Oliver 1990; Stone 1984). In addition, our conceptions of work and disability reflect the way that some social welfare laws define "disability" to mean the inability to work, implicitly constructing work and disability as mutually exclusive categories (Russell 2001; Stone 1984). ${ }^{6}$ Indeed, "work" and "disability" have come to have mutually reinforcing and oppositional cultural meanings that can delegitimate workplace disability claims as "shirking" (Drimmer 1993). ${ }^{7}$ Thus, much more is at stake with FMLA rights than simply changing ad hoc work arrangements; these rights disrupt relations of power between employers and workers and undermine deeply entrenched understandings of work, gender, and disability.

Some civil rights laws that preceded the FMLA attempted to make work more accessible to women and people with disabilities, but these legal reforms have been most successful when they did not reach the core of employer control over the schedule of work. For example, Title VII's provisions regarding gender and pregnancy discrimination have protected the rights of those women able and willing to remain at work and to meet work's institutional requirements, ${ }^{8}$ but have done little for women who need workplace accommodations for their pregnancies such as leaves of absences or more frequent sick days. ${ }^{9}$ Similarly, the Americans with

${ }^{6}$ For example, the Social Security Act defines disability for the purposes of supplemental income replacement as follows:

[A]n individual shall be determined to be under a disability only if his physical or mental impairment or impairments are of such severity that he is not only unable to do his previous work but cannot, considering his age, education, and work experience, engage in any other kind of substantial gainful work which exists in the national economy, regardless of whether such work exists in the immediate area in which he lives, or whether a specific job vacancy exists for him, or whether he would be hired if he applied for work [42 U.S.C. $\S 1382 c(a)(3)]$.

${ }^{7}$ Several scholars have examined how both public policy and cultural conceptions of disability have moved from a medical model of disability to a rights-based model (Burke 2002; Drimmer 1993; Oliver 1990; Scotch 1984). The medical model locates disability in the individual physical or mental characteristics of the individual. In contrast, the rightsbased model focuses on removing environmental factors that create barriers for some individuals and therefore socially construct them as "disabled." This ideological transition has made the ways in which naturalized work practices construct the meaning of disability more visible.

${ }^{8}$ See, e.g., Carney v. Martin Luther Home, Inc. (holding that placing a pregnant worker on mandatory unpaid leave when she remained able to perform her job violated Title VII); $E E O C$ v. Corinth, Inc. (holding that firing a pregnant waitress who was able to work violated Title VII).

${ }^{9}$ See, e.g., Marshall v. American Hosp. Ass'n. (holding that a pregnant woman's need for pregnancy disability leave is sufficient justification for terminating her employment under 
Disabilities Act (ADA) has helped change some workplace structures, most notably physical barriers such as the lack of ramps or accessible bathrooms (Engel \& Munger 1996; Harlan \& Robert 1998). The ADA has been less successful, however, in providing accommodations that modify the standard schedule of work or allow for temporary absences due to illness or treatment (Harlan \& Robert 1998). ${ }^{10}$ In addition, courts have struggled to define who qualifies as both "disabled" within the meaning of the statute and also "able to work." " The confusing and contradictory doctrine on this issue reflects the implicit cultural divide between disability and work. It remains to be seen whether the FMLA's more direct approach of mandating leaves will be more successful in restructuring work.

This study examines how the institution of work affects the process of mobilizing FMLA rights, and it therefore focuses on institutional, social contextual factors and the construction of meaning, rather than on the individual characteristics of rights holders. It asks: How do workers who need leave but encounter resistance from their employer make sense of their situations? How do they understand conflict over leave and their choices about mobilizing their rights? How do institutionalized expectations and norms about work give meaning to these workplace interactions and shape the process of mobilization? And, more broadly, what are the implications for social change through legal reform?

\section{Method and Data}

To answer these questions, this project draws on semi-structured telephone interviews with workers who experienced conflict over leave but did not take their disputes to court. Data such as these are relatively rare because informal disputes generally do not produce court records or other easily obtainable records of the dispute. In addition, employers are rarely enthusiastic about allowing their employees to talk to researchers about conflict over legal

Title VII); Marafino v. St. Louis County Circuit Court (holding that Title VII does not prohibit refusing to hire a pregnant woman because she will require a leave of absence during her first year of work); Dorneyer v. Comerica Bank-Illinois (holding that terminating employees for absences resulting from morning sickness does not violate Title VII).

${ }^{10}$ See, e.g., Terrell v. U.S. Air (rejecting plaintiff's argument that part-time work is a reasonable accommodation); Carr $v$. Reno (holding that "coming to work regularly" is an "essential function" of work); Law v. United States Postal Service (holding that attendance is a minimum function of any job); Jackson $v$. Veterans Admin. (holding that six days of absence in three months due to physical reactions to medical treatment for a disability are not a reasonable accommodation).

"See, e.g., DePaoli v. Abbott Lab. (finding that plaintiff was disabled because she was substantially limited in the major life activity of working, but that her disability rendered her no longer "qualified" to work for the defendant). 
rights. To solve these problems, these respondents were located through a statewide telephone information line in California run by a nonprofit organization that gives informal legal assistance to workers. Attempts were made to contact the universe of individuals who called the information line with questions about family and medical leave during a one-year period. Twenty-four of the thirtyfive individuals in this group agreed to be interviewed, yielding a response rate of almost $70 \% .{ }^{12}$ Despite the small size of this group of workers, these respondents were fairly diverse in terms of age, race, education, marital status, income, and occupation (see Appendix). Quotations in this article are identified by numbers that correspond to the appendix information for each respondent.

The interviews, which typically lasted about forty-five minutes, were tape-recorded and transcribed. The data were then analyzed using NUD*IST, a qualitative analysis software program that allows researchers to identify and code themes as they emerge from the transcripts. The analysis identified common themes in workers' experiences, including the factors that influenced their decisions about mobilizing their rights and the problems they experienced taking leave. This analysis involved multiple readings of the interview transcripts to identify themes regarding the mobilization process as they emerged from the transcripts. Through this process, themes such as "gender," "slackers," and the meaning of "time" emerged from the transcripts to shape my analysis of workers' experiences. I then went back to code each instance of these themes systematically and to analyze patterns among those themes. ${ }^{13}$ NUD*IST greatly simplifies this process by allowing the researcher to mark interview segments associated with a theme, to sort and index these segments by theme, and to analyze patterns among themes.

Like most qualitative studies, the number of interviews analyzed here is small. Although the small number of subjects requires caution in drawing generalizations, the in-depth approach made possible by small- $\mathrm{N}$ studies has the potential to reveal considerable nuance and detail about the mobilization process. Note also that because this study focuses on the experiences of workers who anticipated or experienced some difficulty in obtaining leave, the subjects are not and were not intended to be a random sample of the population of potential leave users. For this reason, I make no claims about how frequently problems with the FMLA arise or

12 Four individuals could not be contacted after multiple attempts, four individuals refused to be interviewed, one number had been disconnected, and two numbers were incorrect.

13 For an excellent discussion of this process in qualitative sociolegal research, see Kritzer 1994. 
about the differences between workers who experience problems and those who do not. Instead, my analysis focuses on how the shadow of social institutions shapes the meaning actors give to leave conflicts and constructs their preferences about mobilizing their rights. More broadly, my analysis details how competing social institutions shape the process of mobilization and construct the meaning of leave, in some instances transforming the meaning of legal rights in the workplace. Accordingly, this inquiry presents a theory-building opportunity to examine how broader social institutions affect informal rights mobilization, as well as the implications of these institutions for inhibiting or facilitating social change.

The qualitative data from this study complement other ethnographic and quantitative studies of family and medical leave (Commission on Leave 1996; Fried 1998; Gerstel \& McGonagle 1999; Hochschild 1997). For example, these data add to quantitative research about patterns of leave-taking in general (see, e.g., Gerstel \& McGonagle 1999) because they access the cognitive processes that contribute to choices about leave and rights. Similarly, this study differs from recent ethnographic studies of leave-taking and corporate culture within a single organization (see, e.g., Fried 1998; Hochschild 1997) because it uses respondents as informants about diverse work settings to identify patterns that bridge multiple workers and workplaces. This approach helps identify institutionalized patterns across workplaces and across organizational boundaries that show how social institutions such as work can shape and transform legal rights.

\section{The Process of Rights Mobilization in the Workplace}

In the sections that follow, I outline two broad themes regarding the process of mobilization: how workplace rights mobilization remains embedded in relations of power, and how the shadow of the social institution of work shapes and transforms the meaning of FMLA rights.

\section{Power and Workplace Rights Mobilization}

\section{Information Control, Agents of Transformation, and Worker Solidarity}

One important theme that emerged from these interviews is that unequal power in the workplace can affect how workers think about rights mobilization. Most respondents mentioned at least one power dynamic that influenced how they thought about mobilizing 
their rights to leave. For example, for some, a threat of termination could silence objections to unfair treatment.

Um, when I was pregnant, my doctor put in writing that I could not, he didn't want me bending for long periods of time, or looking up for long periods of time because I have a tendency to get dizzy and get off balance when you're pregnant. ... So, everything that [my supervisor] wanted me to do was four to six inches from the floor. And there were other courtesy clerks there that could have done the job, but she wanted me to do it. She didn't care if my stomach is showing and everything. There were guys there that were courtesy clerks that could have did the job. And when I told her, "I don't think I'm supposed to be doing this." She'd tell me, "You don't like your job?" You know. And I felt that was pretty cruel, you know for her to treat me that way ... So ... [I did the work and] I ended up losing my baby. ... When I returned to work, she started right back up. She told me that she did everything while she was pregnant with no restrictions. That's what she told me. ${ }^{14}[1017]$

An explicit threat may not be necessary if workers fear other penalties at work. For example, the following respondent did not pursue her right to return to the same or equivalent job after leave, even though her hours were cut in half when she returned to work.

I just didn't want to make-cause he's a new manager and I hadn't worked with him. I didn't want to come back with an attitude and then him kind of be negative toward me. It hurt, but I thought well, I still have my job. It's going to be rough because, you know, 20 hours a week. [1018]

Some respondents worried that being fired would not only deprive them of a job, but also harm their ability to find future employment. They justified voluntarily quitting rather than pursuing their rights and risking termination by pointing out that no one wants to hire a fired worker, particularly a "troublemaker" who sued a former employer.

Power in the employment relation can operate in more subtle ways to shape how workers come to understand and even know about their workplace rights. Along these lines, one theme that emerged from these interviews is that those who control information about rights have an advantage in workplace negotiations over leave. Information is critical to "naming," or saying to oneself that a particular experience has been injurious, and "blaming," or

14 This particular respondent's situation was covered by state law in California, rather than the FMLA. California law requires employers to accommodate pregnancy-related restrictions on the tasks a worker can perform by transferring her to a less strenuous or hazardous or position where that transfer can be reasonably accommodated (Cal. Gov. Code $\$ 12945$ ). This passage also suggests that the respondent's supervisor applied certain norms about ideal workers. That dynamic is discussed in more detail below. 
holding another responsible for the injury (Felstiner, Abel, \& Sarat 1981). Indeed, the FMLA recognizes the link between information and enforcement by placing affirmative obligations on employers to tell workers about their leave rights. ${ }^{15}$ Virtually all respondents mentioned the importance of information about their rights in evaluating their options for mobilization. Arguably, this is to be expected, given that these respondents called a legal information line seeking help; however, some respondents who called already knew about their rights and were seeking legal representation and other forms of assistance. Moreover, despite their diverse work situations, respondents described common patterns through which information about rights was controlled and limited in the workplace. They also described a social process through which they learned about their rights, and the ways in which they informally mobilized this information to their advantage.

Many respondents indicated that their employers attempted to control information in ways that discouraged mobilization and prevented workers from recognizing a legal injury. For example, when workers request leave, employers can stonewall by asserting that the statute does not apply unless the worker can prove otherwise.

I mean the initial reaction ... was just sheer, "We're not going to even use this law because we don't know what we can get away with. We don't know ... if you qualify so until we do, you don't." That was my feeling that's how they treated that law. ... Their whole attitude is stalwart it or whatever the word is, block it the best you can. Make these folks fight for it. ... That's the reaction I got. [1002]

Employers also can simply remain silent and wait to see whether workers recognize that leave rights might apply.

The way [R's employer] is, ... if you don't do your homework they'll let you ride with what you know and if you don't know enough then you shorten yourself. So you had to go in there with as much knowledge as I had you know, to talk to them. [1010]

Informal practices such as these give employers more control over who will take leave, and thus can transform a legal entitlement into a more discretionary benefit. Although information may have been particularly salient for workers who called the legal information line, these findings are consistent with other studies that have found that information about legal rights is both scarce and essential to negotiating successfully with employers (see Harlan \& Robert 1998). The common patterns among these workers' experiences

${ }^{15} 29$ C.F.R. $\S \S 825.301,825.302$. 
suggest how control over information can affect the mobilization process.

Employers can also act as agents of transformation through internal processes that shape how workers understand conflict over leave (Edelman, Erlanger, \& Lande 1993; Felstiner, Abel, \& Sarat 1981). These processes can "drain the dispute of moral content and diffuse responsibility for problems" (Felstiner, Abel, \& Sarat 1981:641). For example, one respondent's concerns about being denied leave were diverted into the Employee Assistance Program (EAP), a counseling program paid for by the employer. The counselor then constructed her problem as a personal issue, rather than a legal violation.

Well, the EAP person at work [was helpful].... He was very understanding and he felt that [my problem] was a rotten deal but, you know, "Hey, there's nothing anybody can do about it." [1006]

By framing this respondent's problem as just the way things are, a product of her personal circumstances, the counselor helped diffuse conflict about leave and deflect a potential legal claim.

Although employers could shape respondents' perceptions by controlling information about FMLA rights, most respondents also talked with friends, family, and others to find information about the law and to discuss possible responses to conflict over leave. These social interchanges with others influenced how these respondents thought about mobilization. For example, this respondent indicated that friends encouraged her to see her situation as a legal violation and to pursue her rights.

I felt like I was kind of in a situation that nobody had really been in, and so I didn't really know what to do. So people's opinions and their thoughts of what I should do made a big impact because I really had no idea of where to go from here. And I have some friends who were very supportive of this and said, "No, you have to go forward with this. You have to go through with it because they can't get away with this." [1015]

Although this respondent's friends encouraged her to mobilize her rights, her stepmother interpreted the situation differently based on her own experience of losing her job before the FMLA was enacted:

I talked to my stepmother, who had three children, and, um, I guess had had maternity leave for each child, for each birth. And she told me, "That's just the way it is." You know, I shouldn't try to fight it, I shouldn't get myself all upset. That it's what happens. [1015]

These conflicting interpretations illustrate how different cultural frameworks-here, acceptance of gender inequality versus 
empowerment by legal norms-can be deployed by agents of transformation in the mobilization process. For this respondent, legal norms that legitimize job-protected leave facilitated mobilization by undermining the interpretation that losing one's job when one has a baby is "just the way it is." Thus, this respondent's experience suggests how legal discourse can generate alternative interpretive frameworks that challenge established patterns of acquiescence to inequality.

In general, for these respondents mobilization was not a solitary decision based on preexisting, endogenous preferences, but instead a social process in which others' opinions about what they should do shaped their choices. In other words, respondents formed their preferences in part in response to norms and perceptions communicated by others. As I explain in more detail below, those norms and perceptions, in turn, were shaped by actors' experiences within existing systems of inequality in the workplace, and by institutionalized conceptions of work, gender, and disability.

Friends, family, and others can act as agents of transformation in several ways. First, they can encourage workers to mobilize their rights, sometimes by framing a particular experience as unacceptable or illegal.

I talked to ... the guy I was co-managing the store with and I talked to another manager [about my situation].... Both of them felt like I had been misled [by the company]. And that [it] had been done purposely.

Interviewer: And did that influence what you did in your situation in any way?

It made me want to talk to somebody in the law. [1008]

Exchanges with others can also warn workers about the risks of claiming rights, however.

You know I've heard horror stories about people taking time off when their baby was born and were getting a lot of flak from their bosses because they took the time.... I heard, there was this one guy, he has a shift that is mid-shift, 12 to $8: 30$ and when he came back to work they changed it on him... They changed his shift to a graveyard shift, Monday through Friday when he came back.... I worked graveyard for four years, I didn't want to go back to that. [1010]

This last example suggests how actions taken against only one worker can influence how many others think about mobilizing their rights. Stories of retaliation, passed through social networks in the workplace, can discourage workers from requesting leave, even absent any explicit threat directed toward them. 
Nevertheless, interactions with agents of transformation do not always discourage mobilization; sometimes social interactions about rights build solidarity among workers. By discussing leave problems with others, workers may uncover a larger pattern of shared grievances. In addition, as the following example illustrates, conversations about leave rights can help build informal networks for pooling knowledge about the law.

Several of us were tempted to get together and get a suit going, but getting together with a lawyer is very difficult. And no one is really willing to commit to helping at all to start it. But all of us had had issues as far as FMLA, knew each other's issues ... so ... we would advise new employees a lot of the time if they had issues come up, they would come to us.... As new people came in we would let them know, we've gone through quite a bit if you need any help with anything as far as your benefits, your health or whatever, just let us know ... We all kind of pooled our knowledge. We all had a much more expansive knowledge of what was going on. As far as influencing me, I didn't think that I could get FMLA [leave] for my condition and one of my coworkers said, "Yes you can." So it did directly affect the course I took. [1021]

In this way, negotiating individual rights can become a collective concern, and workers can gain greater leverage in negotiations over leave.

This last point contradicts the critique that rights undermine collective action by atomizing disputes and isolating grievances from their social context (McCann 1986; Scheingold 1974). This critique may place too much emphasis on how formal rights claims in court atomize grievances by narrowing disputes to legally relevant facts and individualized remedies. This critique also tends to assume that rights mobilization is a solitary, rather than social, process. This assumption overlooks how the informal process of mobilizing rights - finding information about rights and caucusing with other workers about what is appropriate and legal-can help build connections and common interests among grievants. The social process of mobilization may also show workers how rights claims extend beyond their individual interests. Indeed, several respondents said they took steps to pursue their rights to prevent future workers from having a similar experience. ${ }^{16}$

This insight is important because it suggests that individuals who mobilize their rights in informal settings can set in motion a framing process that may lead to eventual collective action

${ }^{16}$ Similar findings on a more macro level have emerged from recent research about rights mobilization by social movements (see McCann \& Silverstein 1998). 
(Snow et al. 1986). Just as rights litigation in courts can provide a public rallying point and publicity for a social movement (McCann 1994), informal rights mobilization through workplace interactions can build solidarity among workers who share common grievances. It can also encourage workers to conceptualize their problems as part of a broader system of power and control. In other words, these data do not seem consistent with the argument that rights are inherently limited as a social change strategy because they frame broader grievances as individual problems. Individual rights do not necessarily create an ideological framework that always causes workers to conceptualize difficulties as individual problems rather than collective concerns. In some instances, the process of sharing information can create a collective framework for interpreting opposition to rights, even if power disparities or coordination problems sometimes prevent formal collective action. Thus, more attention is needed to the context of rights mobilization, particularly social processes within informal contexts, when evaluating the capacity of rights for bringing about social change.

When considering solidarity among workers, one might think that unions would be a key mechanism for helping workers to respond when employers resist FMLA leave. Indeed, two-thirds of the respondents in this study were union members, perhaps reflecting the information line's outreach efforts with unions and other worker organizations. Only about half of the respondents who belonged to unions, however, indicated that the union had been helpful in their negotiations over leave. ${ }^{17}$ The primary form of help provided by respondents' unions was to inform them about the information line and the FMLA. Only two respondents indicated that their union advocated for them in their negotiations over leave. Nevertheless, the experiences of these respondents suggest that unions can play an important role in disseminating information about statutory employment rights. ${ }^{18}$

\section{Law as a Symbolic Resource in Leave Negotiations}

Even for those workers who negotiate their rights on their own, legal rights can be an important symbolic resource. Most respondents reported that they felt empowered by the legal entitlement to

17 Of course, selection bias may be operating here if workers who received substantial help from their unions did not call the information line.

${ }^{18}$ Here is an interesting side note about the effect of unions on realizing FMLA rights. Two respondents believed that their employer had denied them FMLA leave because they were active union leaders. In other words, these respondents were convinced that their employers withheld FMLA leave to retaliate against them because they advocated for other union members in workplace matters. 
leave as they negotiated with their employers. For example, many respondents said they felt morally justified in pursuing claims to leave once they knew that their employer acted illegally. As one worker put it,

[Information about FMLA rights] gave me a leg to stand on. And some kind of moral or ethical support knowing that this is what my rights were. ... [1003]

In addition, many respondents described law as a pragmatic resource for confronting employers, even when they did not make a formal legal claim. For example, this worker used legal knowledge to negotiate successfully with her employer:

[When my employer denied my leave request] I didn't say, "It's not legal," I said, "According to this state statute ..." I put the statute number and stuff, so that they know that I know what I'm talking about ... [A] lot of people will go, "Are you sure this is legal?" ... and then they'll try and like moonshine their way around it. And rather than have people do that to me, I just got to where when stuff comes up, I'll learn the legal statute numbers and it's more effective for me that way.... [Information about my rights] gave me knowledge which gave me the power to act on what was going on. [1021]

Learning about their rights helped these workers frame their experiences in both legal and moral terms and gave them confidence to press for time off. Some workers also drew on law to interpret leave as an entitlement, rather than a personal problem. Thus, these data suggest that even workers who lack financial resources for a court battle can still informally mobilize law to validate their claims to leave.

A prior study of mobilization by Bumiller (1988) suggested that civil rights laws construct meanings that are disempowering rather than empowering. More specifically, Bumiller found that some individuals choose not to pursue civil rights claims to avoid taking on a victim identity. Respondents in my study did not express similar concerns. Of course, not all laws construct the same symbolic meaning. The FMLA frames leave as an entitlement rather than a protection based on status, which may avoid constructing claimants as "victims." In addition, my respondents differ from the "unmobilized" subjects in Bumiller's study in that they took some steps toward mobilization. Nevertheless, even my respondents who abandoned potential claims did not say they did so to avoid the victim label. Accordingly, it may be that whether actors see the law as empowering or disempowering varies with the substance of particular rights. 


\section{Rights Mobilization, Social Institutions, and the Social Construction of Leave}

Perhaps the most subtle form of power is how the established practices and expectations that make up institutions can shape social action to re-create inequalities embodied in those institutions. Along these lines, the following sections discuss three themes that emerged from these interviews that illustrate how workers' leave negotiations are embedded within the social institution of work. First, I examine how family wage ideology, or the assumption that the normative worker is a male breadwinner with a stay-at-home wife, can shape how workers and others think about the meaning of leave rights. Second, I document how a "slacker" narrative can undermine the FMLA in ways that subtly reinforce the constitutive relationship between disability and work. Finally, I look at how employers can reinterpret leave rights in terms of management objectives, weakening the normative power of the law relative to the institution of work.

\section{Family Wage Ideology}

Most respondents who took pregnancy or parental leave discovered that despite the law, family wage discourse framed the meaning of their leave. Indeed, many women found that taking leave changed perceptions of them at work because it seemed to signal that they were no longer committed to their job. For example, one respondent reported that even though her objective performance had been good (as reflected in her performance review), her supervisor's attitude changed after her leave to care for her ill daughter.

He's like, "Well she's having a problem with her kid. ..." [Now] he makes me feel like I'm inadequate. Like I can't do the job, like I'm not bright enough. [1018]

Virtually all of the female respondents had no difficulty initially taking leave, but when they attempted to return, they encountered resistance and perceptions that they were less reliable and committed to their work.

The experience of a respondent who took pregnancy leave for twins illustrates this phenomenon. This respondent worked as a manager for her employer, a large company, for sixteen years before she needed leave. Nevertheless, her employer assumed she would not return and canceled her health insurance while she was in the hospital. In addition, her boss told coworkers that she did not need her job because her husband could support her. 
They were saying, "Well she doesn't need to get paid," my boss was saying. "She has money-her husband is a doctor." [1009]

Despite her years of service, her employer presumed that her husband was the breadwinner, and therefore she did not "need" her job. Her supervisor attempted to justify letting her go by mobilizing a cultural discourse that women (particularly mothers) are and should be economically dependent upon their husbands.

Legal rights also framed her understanding of her situation, however. A friend who was a lawyer told her that she would have a strong legal claim if she tried to return and was fired, and she expressed outrage that her employer ignored her legal entitlement to leave. Nevertheless, she feared that no future employer would hire her once she had been fired. She knew that her employer had fired other long-term employees who needed leave, and she decided to quit.

Those two got fired first and then I just said, you know, I don't want to get fired. I mean I have a good record and I would hate to have to go and start somewhere at, in your mid-thirties and then your employer that you've worked for 16 years fired you? That doesn't look good. And my husband said, "Is it really worth it all?" [1009]

However, when she left, to avoid a confrontation with her employer she told her supervisor she could not return to work because she lacked child care.

This respondent's experience illustrates how legal and nonlegal frames for interpreting leave can shape informal rights negotiations. To decide whether to mobilize her rights, this respondent struggled to reconcile legal discourse with family wage ideology in a context already structured by power, gender, and taken-forgranted expectations about work. Her problems with leave arose in part because gendered assumptions about work and family gave meaning to her use of leave. This same family wage discourse helped obscure how her employer's power to fire her influenced her decision. Although she interpreted her experience as a violation of her rights, she avoided conflict by drawing on a gendered discourse to give a culturally acceptable reason to quit: lack of child care. As a result, on the surface, her actions communicated a voluntary "choice" to stay home and care for her children because her husband could support her; the roles that law and power played in her decision remain invisible. In this way, gendered assumptions about women and work are reinforced, while legal entitlements to leave are simultaneously undermined and obscured.

The male respondents who took family leave had somewhat different experiences. In fact, both male and female respondents reported informal workplace norms that men should not take all 
the parental leave that is legally available to them. For example, in one respondent's workplace, it was unthinkable that a new father would take more than a week or two of leave.

There was another guy who was having a baby and I think that they got more pressure to come back to work, OK, "It's OK for you to take a week off and maybe a week and a half off, but let's not go crazy here." And that wasn't, I don't think they would have been open for the FMLA for the men. At least the men I knew just took their vacation and didn't take, didn't use the FMLA when they could've. Because they were pressured to come back to work, like "Hey, you didn't have a baby."

Interviewer: And there wasn't the same kind of pressure on women?

No. [1020]

While female respondents typically found that they were expected to take leave to care for others, all of the male respondents reported that their employers and coworkers were incredulous and even hostile when they decided to take family leave. Thus, the same family wage discourse constructed different meanings for respondents' leaves depending upon their gender. ${ }^{19}$

These deeply entrenched expectations about work and gender also shape workers' legal consciousness. For example, some male respondents who took unpaid family leave struggled to reconcile leave rights with norms that men should prioritize work over family needs. The experience of the following respondent who took leave to care for his terminally ill wife illustrates this point. This respondent had worked as a laborer for seven years for a public agency in the San Francisco area. When he took leave to care for his wife, he encountered criticism from coworkers for missing work, and also received a disciplinary letter from his employer telling him to keep his leave use to a minimum. When his coworkers, his employer, and even his wife questioned his time away from work, he drew on legal norms to legitimate his leave:

I always made them understand that I'm under family leave ... and that allows me the right [to take leave].... [M]y wife a lot of times, says "Babe, you can't miss this much work," this and that, and I'd say "Honey, you know, I'm not missing work to miss work. You're sick or whatever and if you need me, I'm here and that's what family leave is, that's why I'm under it, and that's why

${ }^{19}$ Other studies have demonstrated consistent and widespread employer hostility toward male workers taking parenting leave. For example, one study found that $63 \%$ of large employers considered it unreasonable for a man to take any parental leave at all, and another $17 \%$ considered a reasonable leave to be no longer than two weeks (see Malin 1998:39-40). 
we fill out the certification papers with your medical provider to protect me in these times of need." [1012]

At the same time, however, he believed he should not seek advancement at work while he might need family leave.

There has been plenty of opportunities for me to move up and stuff, but I didn't pursue them because ... I'm not ready to give $100 \%$ responsibility. My responsibility deals with my wife and family at this time. And I've known how sick she is so I didn't pursue any of those advancements for that reason. It was that my priorities are with my family and not moving up at this time... [W]e are pretty middle class. I mean there is nothing we are deprived of. We probably have more things than what most people got, but that has never been a priority to me, like having more or whatever. You know, my priority is my family and that's how I'd like to keep it. [1012]

This respondent knew about his legal rights, and he was aware that the FMLA prohibits employers from taking leave into account in promotion decisions. ${ }^{20}$ Nevertheless, he understood leave and advancement at work to be an either/or choice-one cannot both pursue a promotion and also care for sick family members. When he justified taking leave by arguing that he passed up opportunities for advancement, he both accepted and reinforced the family wage norm that ideal workers should have no responsibility to care for others. At the same time, his statement that his family is "pretty middle class" despite his choice to put family first implicitly referenced cultural expectations about the male breadwinner role and justified his choice against those norms.

In mobilizing his rights, this respondent ran up against implicit, gendered expectations about what work and being a good worker mean. By referencing his legal rights, this respondent legitimized his choice to put his family first to himself and to those who questioned his absence. That his choice to care for his wife requires justification, however, reveals how these rights are embedded within other systems of meaning that constructed this choice as illegitimate. He reconciled legal rights with these alternative ideologies by simultaneously asserting his rights and voluntarily compromising his advancement at work. In this way, legal and nonlegal discourses interacted to shape his understanding and the practical meaning of his legal rights.

The double bind of meeting expectations about being both a good worker and the family caretaker also affected female respondents, but they struggled with the contradiction between being "good workers" and "good mothers." The following respondent's

\footnotetext{
2029 C.F.R. $\S 825.220$.
} 
experience illustrates this conflict. This respondent had worked in the human resources department of a hotel before taking leave for pregnancy disability and childbirth. When she tried to return to work after her leave, she discovered that her employer had filled her position. She was angry, and when friends suggested that she contact a lawyer about pursuing her rights, she did. At the same time, she worried that she was to blame for her situation because she had violated norms about being a good worker.

I was speaking with a lawyer all that time, trying to get back my job and see if they would offer me anything else, but they just wanted to put me in housekeeping. They couldn't find anything for me. At least that's what they were saying. Other situations they were hiring for, other things like sales. And I was like, "Well I can learn sales, anything." A lot of my friends tell me that it's not my fault, that people are just like that. I felt like I was to blame. I even talked to my boss about it. I said, "Didn't I do a good job?" [1013]

Although her boss assured her that she had performed well, he also demoted her from human resources assistant to hotel housekeeper. She continued to work as a housekeeper for several months while her lawyer negotiated for her job.

Although she continued to negotiate her rights, she also worried about failing to meet her obligations as a mother, saying, "I just felt that no one else would take care of [my child] like a mother would" [1013]. She was ambivalent about returning to work because she no longer had the job she loved, and she had to leave her child with another caretaker to work as a housekeeper for less pay.

I felt bad in my own way and I was very sad. And I think a lot of it was because I knew my child was with this other person. I couldn't do anything about it. My job went to another woman and what was I going to do? All I could do is cry. [1013]

Although some of her friends thought she should continue to fight, others suggested a different solution:

I have one friend, she was always telling me, "If you feel this way why don't you just quit your job and just take care of your son?" Then my husband got a better job offer so that's when I said, I think I will do that. [1013]

Eventually, she gave up her negotiations with her employer and quit her job.

This respondent negotiated her rights within three overlapping and contradictory frames: legal entitlements to leave, institutionalized expectations about what it means to be a good worker, and deeply entrenched norms about what it means to be a good mother. The conflict among these frames made claiming her rights psychologically taxing. She hired a lawyer to fight for her job, but 
she also felt unsure of her claim to being a good worker after missing work for pregnancy leave. At the same time, she worried about not meeting an idealized norm of a mother's intense and personal care (see Hays 1996). Her comments reveal the contradictory legal and cultural schemas about the meaning of leave that framed her decision about mobilization.

This respondent decided to quit, but it is simplistic to interpret her choice as the result of immutable, gendered "preferences" without considering how institutionalized work norms and structural conditions shaped her preferences. Perhaps she would have made a different choice if her employer had allowed her to return to her former management position rather than demoting her to housekeeper. As some feminist scholars have suggested, for working-class women and women of color such as this respondent, meeting the demands of ideal motherhood can be a haven of respectability from race and class discrimination in the market (Davis 2000). By demoting her from manager to housekeeper, the employer may have tipped the relative balance away from low-status market work in favor of motherhood. Also, by suggesting that she should quit and care for her son, her friend framed her situation as a choice between work and motherhood, rather than as a legal violation. Norms about the mutually exclusive roles of mother and worker undermined her resolve to pursue her legal rights and constructed a culturally acceptable solution for resolving her stress. Her choice, channeled in part by the cultural conflict between being a good worker and a good mother, helped reinforce that cultural bind despite the protection of the law.

As these examples illustrate, respondents who took family leave negotiated their rights within a web of meaning made up not only of law, but also of deeply entrenched assumptions about work and gender. Although these respondents negotiated rights within the same web of meaning, the interpretations that flow from those frames varied with gender. As the responses of their employers, friends, and family suggest, culturally, women are expected to quit work to care for new children, whereas men are expected to make work their first priority (Epstein \& Kalleberg 2001; Malin 1998). By deploying this cultural frame, agents of transformation help define the meaning of leave and sometimes identify a cognitive path of least resistance for resolving conflict over leave. In this way, institutions can shape workers' preferences and choices about rights mobilization: by providing a graceful explanation for the first respondent to quit, by defining a compromise through which the second respondent justified his decision to take leave, and by suggesting to the third respondent that quitting to care for others was the solution to her dispute. Because they reinforce gendered conceptions of work and family, however, these paths of least resistance 
help re-create the inequalities that FMLA rights were meant to change.

\section{Slackers and Workers}

Respondents who needed leave for their own serious health condition navigated somewhat different informal workplace norms that labeled leave-taking as shirking. Virtually all of these respondents reported that in their workplaces, despite legal entitlements to leave, "committed" workers were expected to come to work even when sick. Conversely, workers who were unwilling or unable to work while sick were perceived as less valuable.

There seemed to be kind of, I forgot the proper way to word this, the company's attitude towards people working when they're ill and working to the point of causing illness, that was sort of a badge of courage. And I had seen other people in the company pretty much be discounted as valuable employees because they wouldn't or couldn't work when they were sick. And I think that's where my fear came from. [1008]

Both employers and co-workers sometimes interpreted taking leave as shirking, as this long-time employee of a public transit company explained.

Well some people consider that you're a slacker or whatever... because you're off. They don't consider sick at any point. They know I'm very energetic and hyper and all this stuff, but I should just retire or quit or whatever. I'm in the way. ... Some people who are real company-oriented or upward, yuppie types feel like you're not being a good employee if you're off. Even if you do the job efficiently. [1003]

Employers communicate this norm through concrete practices such as passing over leave-takers for promotion, transferring (or refusing to transfer) them, cutting their hours, or assigning them undesirable work. These practices mark those who take leave as poor workers, despite legal rights to leave. ${ }^{21}$

Everyday workplace practices can help reinforce perceptions that taking leave for an illness is a form of shirking. For example, not replacing workers who take leave can encourage hostility toward leave-takers, as this employee of a large health maintenance organization described.

Like for instance the, well the FMLA they have to give you. But what they do is some departments and most of the departments

21 Many of these practices are technically illegal. For example, the FMLA prohibits discrimination against workers who use leave rights, including using the taking of leave as a negative factor in employment actions such as hiring, promotions, or disciplinary actions (29 C.F.R. $\S 825.220$ ). However, these kinds of claims can be very difficult to prove. 
actually, they won't replace you when you get sick, so it causes peer pressure and creates hostility. ... amongst your own coworkers. ... "Well if this person didn't have so much family leave all the time," you know, that type of situation. .. . You call in and say, "I'm sick, I'm taking a family leave day." But the end result of that is that it creates hostility in the workplace. They're not supportive because the employer doesn't replace the person. [1006]

This particular workplace practice deflects blame for the extra workload away from the employer because it frames workload problems as a conflict among workers, rather than between workers and the employer. Although the law has changed, this workplace continued to be structured around the always-ready, alwayspresent worker; the employer lacked any contingency plan or substitute staff to cover workers on leave.

The slacker discourse suggests how systems of meaning other than law can create resistance to rights and discourage workers from using leave. By drawing upon the cultural image of the slacker, employers and co-workers reinterpret mandatory leave rights as a form of shirking. It is important to realize that the slacker judgment is not a spontaneous local norm; its roots lie in the historical construction of work as an institution. The slacker image reflects assumptions that work and disability are mutually exclusive and that therefore one cannot legitimately claim to be both a worker and disabled. In other words, the slacker label references deeply held beliefs that being "really" disabled means not being able to work at all. Accordingly, leave-takers find themselves straddling the cultural line between disability and work and disrupting the mutually constitutive relationship between the two. The slacker discourse both reflects and polices this line by penalizing workers who claim a disability, however temporary that disability may be. ${ }^{22}$

Nevertheless, workers can draw on law as a symbolic discourse to reconstruct the meaning of taking leave, as this respondent discovered.

What I've done because of this situation and because I've heard all these things, is I've been meeting with groups of employees

22 An alternative explanation for the slacker image might be employers' and coworkers' concerns about abuse of sick leave. Curiously, however, the "slacker" discourse seemed to apply even when there was no question that the worker's use of leave was legitimate. For example, one respondent reported that coworkers harassed a worker for taking leave, even though they were aware that her leave was for a documented brain tumor. Similarly, several respondents who had provided medical certification of their need for leave still found their absences interpreted as "shirking." Thus, it seemed to be simply an extended absence itself, even if medical documentation was provided, that triggered the slacker discourse. It also bears mentioning that what is considered "abusive behavior" is itself often defined against institutionalized workplace policies that typically allow only a small number of sick days per year. 
and telling them that you don't need to go there. People are entitled to this [leave]. If it was you or your family member you would want this leave too. And you sure wouldn't want to come back to work and find out that your own coworkers are being ugly about it. And if they don't replace you, it's not the employee's fault. It actually has to do with the employer. And trying to appease people. I talk to them and explain to them what the rules are and explain to them that the person who is the sick person, is entitled to this time. And you're just making it worse by doing this to them.

Interviewer: And how has this been received?

Actually pretty good. I've been trying to get them not to fuss with each other. ... [1006]

This respondent drew on legal rights to undermine the slacker discourse. First, she explained "what the rules are": that leave is an entitlement, and therefore not subject to qualification or discussion. Second, she referenced legal norms of equal treatment by pointing out that all workers can benefit from the FMLA's protections. She also undercut the employer's slacker interpretation by pointing out that management, not the absent worker, controls workload distribution. This legal counterdiscourse reveals how the slacker label obscures the employer's responsibility for the increased workload. Legal norms also undermine the norm that "good workers" work while sick because legal norms help legitimize time off for temporary illnesses.

This example illustrates how workers can draw on law as a symbolic resource to challenge institutionalized practices and meanings in workplace negotiations over leave. In these microinteractions, legal discourse can disrupt existing social practices and reveal alternative ways of organizing work life. To the extent that larger social structures are created and re-created through micro-interactions such as these (Sewell 1992), law as a counterdiscourse can be one mechanism for bringing about social change.

\section{Managerial Norms and Needs}

FMLA rights also clash with another institutionalized work practice: employers' unilateral control over the schedule of work. Legal reforms can have difficulty penetrating institutionalized practices such as these because they shape how managers respond to the law. For example, Edelman, Erlanger, \& Lande (1993) show how organizational conflict managers reinterpret civil rights objectives in terms of managerial norms. Two-thirds of the respondents in this study reported similar patterns in which employers used informal workplace practices to regain control over time off. 
Some management strategies for taking back control reflected staffing concerns. For example, one respondent's employer told him about his rights to parental leave, but then asked him not to use them because the employer was short staffed. Another strategy was to limit informally the number of workers who took leave at any one time.

[My supervisor] said well "So and so's on family leave and this one's on family leave and they haven't complained." Yeah they're not working it the same way with them. And then ... she was telling me that they had family leave but that we couldn't discuss it. And then she says, "Oh someone else is applying for family leave, but we tried to keep [the number of people on leave] down to one a line." ... And I'm saying "Hey, that's not what the law says."

Interviewer: And what did she say when you said that?

"Well, that's just what we try to do." [1003]

A second respondent's employer also seemed to manage leave requests in a way that minimized staffing concerns.

Depending upon your job position you were treated differently.

Interviewer: Oh really? And how was that, I mean which jobs were treated better and which were treated worse?

Well, I was treated worse. And I was a hostess. And the server that had had the same experience, she was treated better because I think there was more room for her to be accommodated in the schedule because there's 30 servers but there's only three hosts.... They just ... it's again, whatever's convenient for them. It's not about the law with them. [1015]

Note that these employers did not completely ignore the law. They complied at least partially by telling workers about their rights, or by allowing some workers to take leave. Nevertheless, they implemented the law in a way that emphasized managerial norms about work schedules and staffing, rather than the entitlement to leave in the statute. In other words, these informal workplace practices did not produce "order without law," but instead subtly transformed leave rights in the workplace to be consistent with managerial needs.

Managerial practices could affect workers' choices about leave in more subtle ways as well. For example, one respondent described how a management scheme that rewarded workers for meeting production targets undermined leave rights.

[I]t was bad because we were self-directed, there was a lot of talk about you know, how will [the new law] affect us, as far as covering production numbers and all that when people take and make use of this Act.... They diffuse everything because they get 
this self-directed, you're your own boss team-oriented thing. . . In order of importance it's production, safety and whatever after that. Who knows. Production and safety is all we had to worry about. Fly like a bat out of hell, get it out the door, but don't hurt yourself. [1002]

As Burawoy notes, by setting workplace rules and production standards and then allowing workers to run the production process, employers can "manufacture" consent to production norms and rules:

[J]ust as playing a game generates consent to its rules, so participating in the choices capitalism forces us to make also generates consent to its rules, its norms. It is by constituting our lives a series of games, a set of limited choices, that capitalist relations not only become objects of consent but are taken as given and immutable. We do not collectively decide what the rules of making out will be: rather, we are compelled to play the game, and we then proceed to defend the rules. (Burawoy 1979:93)

By setting goals solely in terms of production and safety, and then rewarding self-directed workers for meeting those goals, employers can create "rules of the game" that undermine collective support for leave. In this workplace, workers enforced time standards against each other to ensure that they met their production goals, and in the process reinforced and legitimated work practices that devalue leave. Other possible and desirable goals, such as balancing production needs against a worker's need for leave, were not considered. In addition, to the extent the workers bought into managerial norms, these norms could diffuse worker resistance by providing ready justifications for resisting leave.

The point here, of course, is not that managerial needs are not pressing or "real" in some sense, any less than workers' needs for leave are pressing and real. The law, however, changes the balance of power between employers and workers by removing employers' unilateral control over scheduling and giving workers an entitlement to leave. Previously, employers could solve their managerial requirements by overriding the needs of workers; now the FMLA requires employers to solve their staffing requirements in other ways. Nevertheless, these data show how rather than developing new organizational strategies to address staffing concerns, employers can subtly reassert their control over the timing and schedule of work in ways that resist and transform legal mandates to the contrary. Although these respondents recognized and resisted this transformation, other workers may have simply accepted their employers' reinterpretation of their rights and not taken leave. Reformulating rights in this way can help employers regain control over work schedules without appearing to refuse to comply with the law. 


\section{Conclusion}

Law is an authoritative institution, and for this reason, legal rights seem to be an obvious solution to workplace conflict over family and medical leave. This study cautions, however, that workers negotiate for leave not only in the shadow of the law, but also in the shadow of other social institutions. Workplace rights mobilization remains embedded within existing practices, deeply held beliefs, and taken-for-granted expectations about work, gender, and disability, all of which can create subtle but persistent resistance to these new rights. This social context has important implications for civil rights laws, which are primarily enforced through an individual, private right of action that workers negotiate within these conflicting meanings. Nevertheless, the institutional context of civil rights also creates opportunities to build new coalitions and shape new meanings for family and medical leave. Thus, as I elaborate in more detail below, institutional embeddedness can be seen as both a constraint on and an opportunity for social change.

This study extends beyond the familiar conclusion that local norms can compete with the law. It shows how local practices and norms can have roots in larger social structures, including the very social institutions that the law was intended to change. For example, workplace rights negotiations are embedded within unequal relations of power that are inherent in the employment relation. Formally, rights appear to be nonnegotiable entitlements enforceable by law. In practice, however, legal conflict over leave rights may never arise because workers fear shift changes, bad relations with managers, or the stigma of termination if their employer retaliates. In addition, employers can shape how workers understand and respond to conflict over leave simply by exercising their control over the workplace to limit information about rights.

Note also that power goes deeper than just the unequal power structure of employment. It also resides in institutionalized norms about work and its implicit relation to gender and disability. By enacting the FMLA, Congress did not eradicate deeply entrenched beliefs about work that shape perceptions that leave-takers are shirkers, or that women do not need their jobs because they can be supported by their husbands. In addition, cultural ideologies and material practices can work together to resist rights. Workplace structure may determine, for example, which cultural frame is most likely to be deployed, as employers' strategies for controlling information suggest. Conversely, cultural meanings such as the slacker narrative can obscure how employers exercise power over work rules, such as production goals or staffing levels. In the workplaces in this study, these factors combined to reinforce 
existing conceptions of work that disadvantaged women and people with disabilities.

Thus, rights face resistance from local norms, and these alternative ideologies can arise from the very institutionalized practices and meanings that civil rights attempt to change. Note that this finding contradicts the argument that "rights talk" in our society displaces other cultural norms (Glendon 1991). Instead, new civil rights become one of many competing cultural frameworks for interpreting social interactions; they do not always dominate in social interactions. In fact, because these rights must be individually mobilized in the context of these entrenched and competing meanings, alternative ideologies may continue to control informal workplace practices despite the formal mandates of the law.

This study also confirms new institutionalist insights about how institutions can shape agency, in contrast to interpretations that treat mobilization decisions as rational choices based on preexisting preferences. Indeed, these data suggest that institutions shape perceptions, preferences, and choices, and that treating these larger social forces as atomized, individual "preferences" obscures how social structure constrains choices about mobilization. For example, family, friends, and coworkers all act as agents of transformation by drawing on both legal and nonlegal cultural discourses to interpret the meaning of leave. In this way, these actors help shape what workers believed to be appropriate and possible responses to their situations. In addition, when agents of transformation articulate cultural schemas that conflict with legal entitlements, they can create uncertainty within the minds of workers about what they normatively should do. In short, the institutional context of civil rights constrains not only which options are practically available, but also which options seem legitimate and appropriate. This is in part because preferences about mobilization do not seem to be preexisting and static; instead, they emerge from an interactive social process that is shaped by existing cognitive and normative structures, sometimes in ways that undermine civil rights goals.

Ironically, formal rights may obscure how institutions and power shape agency because rights appear to provide a legal remedy when employers resist leave. For example, when women quit their jobs without asserting their rights, it may confirm deeply held beliefs that most women prefer caring for children to work because those who prefer to work could sue. But relying on objective behavior alone to interpret preferences ignores how power and legal norms influenced these respondents. It also misses how unequal power can help prevent legal disputes from arising in the first place, even when workers recognize their legal rights. For this reason, qualitative studies that reveal the subjective interplay of these factors are particularly important. 
What are the implications of this study for rights and social change? One must exercise caution in answering this question in light of the powerful critique of rights that has been developed by law and society scholars in recent years. Nevertheless, while acknowledging rights' limitations, it is also important to explore in what ways and in what contexts rights might in fact make a difference. And, in a system in which important social values are enforced almost exclusively through private rights of action, the utility of rights must be evaluated in comparison to the alternative - no rights at all (Matsuda 1989; Minow 1987; P. Williams 1991).

The data reported here problematize one claim about rights that they undermine collective action because they inherently create a consciousness among actors that frames grievances as individual problems. Instead, respondents in this study indicated that the existence of legal rights prompted them to talk with others about their experiences in the workplace, to discuss whether their employers' actions were legitimate, and in some instances, to band together to resist their employer's reinterpretation of family and medical leave. In this sense, then, informal rights mobilization can be understood as a social, rather than individual, process of meaning construction as well as action. This process may give rise to symbolic frameworks that delegitimize taken-for-granted practices, such as firing workers who need family or medical leave, and in this way help change deeply entrenched beliefs about work, gender, and disability.

One must be cautious, of course, not to overstate this point, particularly given that this study reveals how social institutions can constrain social change by displacing law or transforming it to be consistent with existing practices and norms. Nevertheless, respondents' experiences also suggest that rights can operate as a powerful cultural discourse in informal negotiations over leave. One cannot dismiss out of hand the symbolic importance of rights claims in the workplace and the instrumental gains that workers sometimes achieve by simply pointing out that an employer's action is illegal. Respondents not only reported feeling empowered by learning about their rights, but also in some instances obtained tangible results by confronting their employer with the law. Thus, rights can still matter even when workers lack the resources to hire an attorney and pursue a formal legal claim.

Moreover, to the extent that the powerful as well as the powerless buy into the legitimacy of legal claims, rights discourse has a deep cultural resonance, both for workers and their employers, and therefore gives workers some agency to make their grievances heard. As Sewell points out, by deploying alternative schema, agents are "capable of exerting some degree of control over the social relations in which [they are] enmeshed, which in turn implies 
the ability to transform those social relations to some degree" (1992:20). Without legal rights, these workers would not have access to the symbolic counterdiscourse of law to resist, and perhaps transform, dominant discourses about work, gender, and disability. Indeed, if one takes seriously the social constructivist claim that institutions do not exist apart from the social interactions that recreate them, then the ability to disrupt and transform meaning by invoking rights becomes a significant mechanism of social change.

In short, the institutional embeddedness of rights mobilization creates both constraints on and opportunities for change. Although legal rights may not always be the dominant normative system, legal entitlements help make the contradictions in workers' circumstances more visible. They reveal cracks in the hegemonic institution of work and allow workers to question the idea that penalties for leave are natural and normal. Certainly, pervasive practices and expectations can constrain social change by resisting rights, but norms can also change in response to legal reforms. The FMLA provides an alternative interpretive framework through which work can be restructured, reinterpreted, and reimagined, and in this way it may help bring about social change.

\section{References}

Berger, Peter L., \& Thomas Luckman (1967) The Social Construction of Reality. New York: Anchor Books.

Bourdieu, Pierre (1977) Oulline of a Theory of Practice. Cambridge: Cambridge Univ. Press.

Bumiller, Kristin (1988) The Civil Rights Society. Baltimore: Johns Hopkins Univ. Press.

Burawoy, Michael (1979) Manufacturing Consent. Chicago: Univ. of Chicago Press.

Burke, Thomas F. (2002) Lauyers, Lawsuits, and Legal Rights. Berkeley: Univ. of California Press.

Burstein, Paul (1991) "Legal Mobilization as a Social Movement Tactic: The Struggle for Equal Employment Opportunity," 96 American J. of Sociology 1201-25.

Burstein, Paul, \& Kathleen Monaghan (1986) "Equal Employment Opportunity and the Mobilization of Law," 20 Law छ Society Rev. 355-88.

Commission on Leave (1996) "A Workable Balance: Report to Congress on Family and Medical Leave Policies." Washington, DC: Commission on Family and Medical Leave.

Davis, Adrienne D. (2000) "Straightening It Out: Joan Williams on Unbending Gender," 49 American Univ. Law Rev. 823-49.

Drimmer, Jonathan C. (1993) "Cripples, Overcomers, and Civil Rights: Tracing the Evolution of Federal Legislation and Social Policy for People with Disabilities," 40 UCLA Law Rev. 1341-410.

Edelman, Lauren B., Howard S. Erlanger, \& John Lande (1993) "Internal Dispute Resolution: The Transformation of Civil Rights in the Workplace," 27 Law E Society Rev. 497-534.

Edelman, Lauren B., Christopher Uggen, \& Howard S. Erlanger (1999) "The Endogeneity of Legal Regulation: Grievance Procedures as Rational Myth," 105 American J. of Sociology 406-54. 
Edwards, Richard (1979) Contested Terrain: The Transformation of the Workplace in the Twentieth Century. New York: Basic Books, Inc.

Ellickson, Robert C. (1991) Order Without Law: How Neighbors Settle Disputes. Cambridge: Harvard Univ. Press.

Engel, David M., \& Frank W. Munger (1996) "Rights, Remembrance, and the Reconciliation of Difference," 30 Law \& Society Rev. 7-53.

Epstein, Cynthia Fuchs, \& Arne L. Kalleberg (2001) "Time and the Sociology of Work," 28 Work and Occupations 5-16.

Ewick, Patricia, \& Susan S. Silbey (1998) The Common Place of Law: Stories from Everyday Life. Chicago: Univ. of Chicago Press.

Felstiner, William L. F., Richard L. Abel, \& Austin. Sarat (1981) "The Emergence and Transformation of Disputes: Naming, Blaming, Claiming ...," 15 Law E' Society Rev. $631-54$.

Finkelstein, Victor (1980) Attitudes and Disabled People. New York: World Rehabilitation Fund, Inc.

Folbre, Nancy (1991) "The Unproductive Housewife: Her Evolution in NineteenthCentury Economic Thought," 16 Signs 463-84.

Foucault, Michel (1979) Discipline and Punish. New York: Vintage Books.

Frank, Meryl, \& Robyn Lipner (1988) "History of Maternity Leave in Europe and the United States," in E. F. Zigler \& M. Frank, eds., The Parental Leave Crisis: Toward a National Policy. New Haven: Yale Univ. Press.

Fraser, Nancy, \& Linda Gordon (1994) "A Genealogy of Dependency: Tracing a Keyword of the U.S. Welfare State," 19 Signs 309-36.

Fried, Mindy (1998) Taking Time: Parental Leave Policy and Corporate Culture. Philadelphia: Temple Univ. Press.

Galanter, Marc (1974) "Why the Haves Come Out Ahead: Speculations on the Limits of Legal Change," 9 Law \& Society Rev. 95-160.

Gerstel, Naomi, \& Katherine McGonagle (1999) "Job Leaves and the Limits of the Family and Medical Leave Act: The Effects of Gender, Race and Family," 26 Work and Occupations 510-34.

Glendon, Mary Ann (1991) Rights Talk: The Impoverishment of Political Discourse. New York: Free Press.

Glenn, Evelyn Nakano (2002) Unequal Freedom: How Race and Gender Shaped American Citizenship and Labor. Cambridge: Harvard Univ. Press.

Gordon, David M., Richard Edwards, \& Michael Reich (1982) Segmented Work, Divided Workers: The Historical Transformation of Labor in the United States. Cambridge: Cambridge Univ. Press.

Gramsci, Antonio (1971) Selections from the Prison Notebooks. New York: International Publishers.

Harlan, Sharon L., \& Pamela M. Robert (1998) "The Social Construction of Disability in Organizations," 25 Work and Occupations 397-435.

Hays, Sharon (1996) The Cultural Contradictions of Motherhood. New Haven: Yale Univ. Press.

Heimer, Carol A. (1999) "Competing Institutions: Law, Medicine, and Family in Neonatal Intensive Care," 33 Law E Society Rev. 17-66.

Hochschild, Arlie (1997) The Time Bind: When Work Becomes Home and Home Becomes Work. New York: Metropolitan Books.

Hull, Kathleen E. (2003) "The Cultural Power of Law and the Cultural Enactment of Legality: The Case of Same-Sex Marriage," 28 Law and Social Inquiry 629-57.

Jacob, Herbert (1992) "The Elusive Shadow of the Law," 26 Law \& Society Rev. 565-90.

Jacoby, Sanford M. (1985) Employing Bureaucracy: Managers, Unions and the Transformation of Work in American Industry, 1900-1945. New York: Columbia Univ. Press.

Kalleberg, Arne L. (1995) "Part-Time Work and Workers in the United States: Correlates and Policy Issues," 52 Washington and Lee Law Rev. 771-98. 
Kamerman, Sheila B., Alfred J. Kahn, \& Paul Kingston (1983) Maternity Policies and Working Women. New York: Columbia Univ. Press.

Kessler-Harris, Alice (1982) Out to Work: A History of Wage-Earning Women in the United States. Oxford: Oxford Univ. Press.

- (2001) In Pursuit of Equity: Women, Men and the Quest for Economic Citizenship in 20th-Century America. Oxford: Oxford Univ. Press.

Krieger, Linda (2000) "Afterword: Socio-Legal Backlash," 21 Berkeley J. of Employment and Labor Law 475-519.

Kritzer, Herbert M. (1994) "Interpretation and Validity Assessment in Qualitative Research: The Case of H.W. Perry's Deciding to Decide," 19 Law and Social Inquiry 687-724.

Lempert, Richard (1976) "Mobilizing Private Law: An Introductory Essay," 2 Lau E Society Rev. 173-89.

- (1998) "A Resource Theory of the Criminal Law: Exploring When It Matters," in B. G. Garth \& A. Sarat, eds., How Does Law Matter? Evanston, IL: Northwestern Univ. Press.

Lukes, Steven (1974) Power: A Radical View. London: Macmillan Press.

Macaulay, Stewart (1963) "Non-Contractual Relations in Business: A Preliminary Study," 28 American Sociological Rev. 55-68.

MacKinnon, Catharine A. (1989) Toward a Feminist Theory of the State. Cambridge: Harvard Univ. Press.

Malin, Martin H. (1998) "Fathers and Parental Leave Revisited," 19 Northern Illinois Univ. Law Rev. 25-56.

Marshall, Anna-Maria (1998) "Closing the Gaps: Plaintiffs in Pivotal Sexual Harassment Cases," 23 Law and Social Inquiry 761-93.

- (2003) "Injustice Frames, Legality, and the Everyday Construction of Sexual Harassment," 28 Law and Social Inquiry 659-89.

Matsuda, Mari J. (1989) "When the First Quail Calls: Multiple Consciousness as Jurisprudential Method," 11 Women's Rights Law Reporter 7-10.

McCann, Michael. (1986) Taking Reform Seriously. Ithaca: Cornell Univ. Press.

(1994) Rights at Work: Pay Equity Reform and the Politics of Legal Mobilization. Chicago: Univ of Chicago Press.

_ (1998) "How Does Law Matter for Social Movements?" in B. Garth \& A. Sarat, eds., How Does Law Matter? Evanston, IL: Northwestern Univ. Press.

McCann, Michael, \& Helena Silverstein (1998) "Rethinking Law's 'Allurements," in A. Sarat \& S. Scheingold, eds., Cause Lawyering: Political Commitments and Professional Responsibilities. New York: Oxford Univ. Press.

McEvoy, Arthur (1998) "Freedom of Contract, Labor, and the Administrative State," in H. N. Scheiber, ed., The State and Freedom of Contract. Stanford: Stanford Univ. Press.

Miller, Richard E., \& Austin Sarat (1981) "Grievances, Claims and Disputes: Assessing the Adversary Culture," 15 Law \& Society Rev. 525-66.

Minow, Martha (1987) "Interpreting Rights: An Essay for Robert Cover," 96 Yale Law J. 1860-915.

Mnookin, Robert, \& Lewis Kornhauser (1979) "Bargaining in the Shadow of the Law: The Case of Divorce," 88 Yale Law J. 950-97.

Montgomery, David (1976) "Workers' Control of Machine Production in the Nineteenth Century," 17 Labor History 485-509.

(1987) The Fall of the House of Labor: The Workplace, the State and American Labor Activism, 1865-1925. Cambridge: Cambridge Univ. Press.

Morgan, Phoebe A. (1999) "Risking Relationships: Understanding the Litigation Choices of Sexually Harassed Women," 33 Law E Society Reu. 67-91.

Nelson, Robert, \& William P. Bridges (1999) Legalizing Gender Inequality: Courts, Markets, and Unequal Pay for Women in America. Cambridge: Cambridge Univ. Press. 
Nielsen, Laura Beth (2000) "Situating Legal Consciousness: Experiences and Attitudes of Ordinary Citizens about Law and Street Harassment," 34 Law \& Society Rev. 1055.

Okin, Susan Muller (1989) Justice, Gender and the Family. New York: Basic Books, Inc.

Oliver, Michael (1990) The Politics of Disablement: A Sociological Approach. New York: St. Martin's Press.

Pateman, Carole (1988) The Sexual Contract. Stanford: Stanford Univ. Press.

Quinn, Beth A. (2000) "The Paradox of Complaining: Law, Humor, and Harassment in the Everyday Work World," 25 Law and Social Inquiry 1151-85.

Rosenberg, Gerald N. (1991) The Hollow Hope: Can Courts Bring About Social Change? Chicago: Univ. of Chicago Press.

Russell, Marta (2001) "Disablement, Oppression, and the Political Economy," $12 \mathrm{~J}$. of Disability Policy Studies 87-95.

Sarat, Austin, \& Thomas R. Kearns (1993) "Beyond the Great Divide: Forms of Legal Scholarship and Everyday Life," in A. Sarat \& T. R. Kearns, eds., Law in Everyday Life. Ann Arbor: Univ. of Michigan Press.

Scheingold, Stuart A. (1974) The Politics of Rights. New Haven: Yale Univ. Press.

Schor, Juliet B. (1992) The Overworked American: The Unexpected Decline of Leisure. New York: Basic Books.

Schultz, Vicki (1990) "Telling Stories About Women and Work: Judicial Interpretations of Sex Segregation in the Workplace in Title VII Cases Raising the Lack of Interest Argument," 103 Harvard Law Rev. 1749.

Scotch, Richard K. (1984) From Good Will to Civil Rights: Transforming Federal Disability Policy. Philadelphia: Temple Univ. Press.

Scott, W. Richard (1995) Institutions and Organizations. Thousand Oaks, CA: Sage Publications.

Sewell, William H. (1992) "A Theory of Structure: Duality, Agency, and Transformation," 98 American J. of Sociology 1.

Shiu, Patricia, \& Catherine Albiston (1995) "Certification Provisions for Family and Medical Leave," 1995 California Employment Law Reporter 253.

Snow, David A. Jr., E. Burke Rochford, Steven K Worden, \& Robert D. Benford (1986) "Frame Alignment Processes, Micromobilization, and Movement Participation," 51 American Sociological Rev. 464-81.

Stone, Deborah A. (1984) The Disabled State. Philadelphia: Temple Univ. Press.

Swidler, Ann (1986) "Culture in Action: Symbols and Strategies," 51 American Sociological Rev. 273-86.

Thompson, E. P. (1967) "Time, Work-Discipline, and Industrial Capitalism," 38 Past and Present 56-97.

Tomlins, Christopher L. (1993) Law, Labor and Ideology in the Early American Republic. Cambridge: Cambridge Univ. Press.

Tucker, James (1993) "Everyday Forms of Employee Resistance," 8 Sociological Forum $25-45$.

Williams, Joan (1989) "Deconstructing Gender," 87 Michigan Law Rev. 797.

- (2000) Unbending Gender: Why Families and Work Conflict and What to Do About It. Oxford: Oxford Univ. Press.

Williams, Patricia (1991) The Alchemy of Race and Rights. Cambridge: Harvard Univ. Press. 


\section{Cases Cited}

Carney v. Martin Luther Home, Inc., 824 F.2d 643 (8th Cir. 1987).

Carr v. Reno, 23 F.3d 525, 529 (D.C. Cir. 1994).

DePaoli v. Abbott Lab., 144 F.3d 668 (7th Cir. 1998).

Dormeyer v. Comerica Bank-Illinois, 223 F.3d 579 (7th Cir. 2000).

EEOC v. Corinth, Inc., 824 F.Supp. 1302 (N.D. Ind. 1993).

Jackson v. Veterans Admin., 22 F.3d 277 (1 l th Cir. 1994).

Law v. United States Postal Service, 852 F.2d 1278 (Fed. Cir. 1988).

Marafino v. St. Louis County Circuil Court, 707 F.2d 1005 (8th Cir. 1983).

Marshall v. American Hosp. Ass'n., 157 F.3d 520 (7th Cir. 1998).

Terrell v. U.S. Air, 132 F.3d 621 (11th Cir. 1998).

\section{Statutes Cited}

California Family Rights Act, California Government Code $\S 12945$.

Family and Medical Leave Act, 29 U.S.C. $\$ 2611$ et seq.

Social Security Act, 42 U.S.C. $\S 1382 \mathrm{c}(\mathrm{a})(3)$.

Catherine Albiston is Acting Professor of Law in the Jurisprudence and Social Policy Program, Boalt Hall School of Law, University of Califormia, Berkeley. She is an interdisciplinary scholar whose work spans law, sociology, and feminist theory. Her research interests include the empirical study of employment discrimination, rights mobilization, the legal profession, the relationship between law and social inequality, and the relationship between law and social change. 


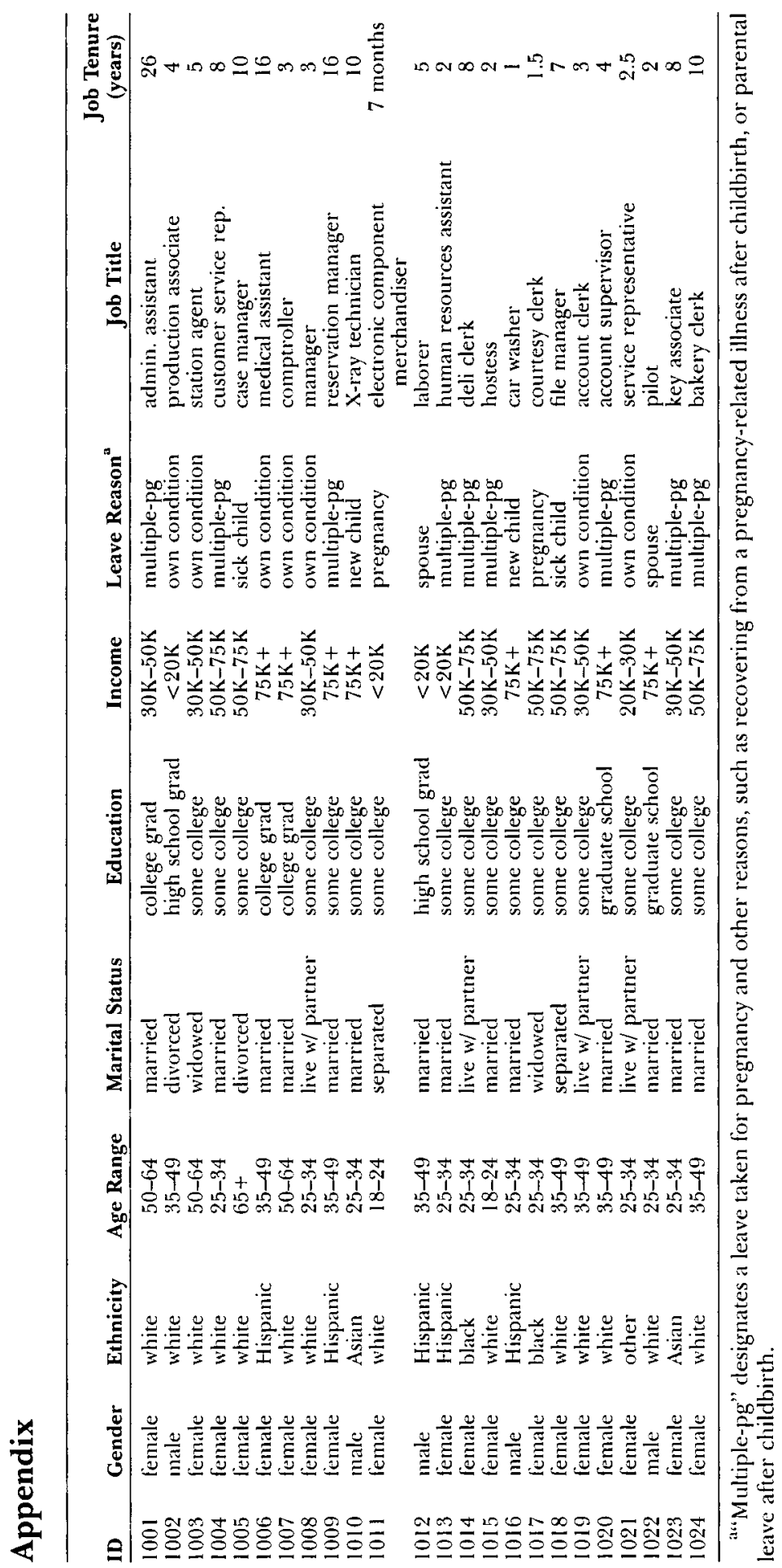


